\title{
WAS THERE A KUSANA RACE?
}

\author{
By BARoN A. voN STAËL-HOLSTEIN
}

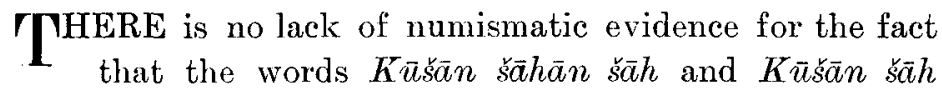
were used as personal attributes by certain princes reigning about the year A.D. 300. On the obverse of one of the coins in question Professor Marquart reads the legend:

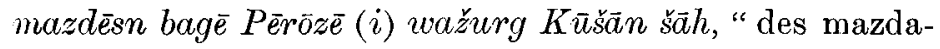
verehrenden Gottes Pērōz, grossen Königss der Kūšān." II. Drouin translates the same legend as follows: "le mazdéen, le divin Pérose, grand Kouchan, roi." 1

It would be difficult to decide which of these two

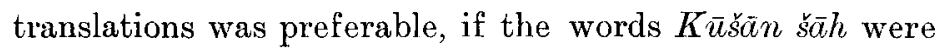
always preceded or followed by a personal name. This, happily, is not the case. Ibn Khordadbeh, ${ }^{2}$ who wrote in the ninth century A.D., gives a list of many royal titles, and tells us that the title of the King of Transoxania (

This enables us to state positively that the title $K \bar{u} \bar{s} \bar{a} n$ $\bar{s} \bar{a} h$, "king of the Küšsan," enjoyed a great prestige in A.D. 300, and was not forgotten even in the ninth century of the Christian era.

${ }^{1}$ See Marquart, Ëränšahrnach der Geographie des Ps. Moses Xorenac'i, Berlin, 1901, p. 49, and Drouin, Revue numismatique, 1896, p. 170.

2 The author of the fundamental work Turkestan at the time of the Mongol Invasion, by W. Barthold, St. Petersburg, 1900 (in Russian), drew my attention to p. 98 of his book, where, while discussing the title $K \bar{u} s \bar{a} \bar{n} n \breve{s}_{\bar{a}} h$, he refers to Ibn Khordadbeh (cf. de Goeje's edition of the latter's Liber Viarum et Regnorum, Bibliotheca Geographorum Arabicorum, pars sexta, text p. 40, transl. p. 29). Cf. also Annales quos scripsit . . Tabari, secunda series, iii, Recensuerunt I. Guidi, D. H. Müller, et M. J. de Goeje, Lugd. Bat., 1885-9, p. 1449, 1. 21. 
We find the earliest mention of the Chinese form of the title $K \bar{u} \bar{s} \bar{a} n$ ša $h$, viz. $K u e i$-shuang-wang, in the phrase ${ }^{1}$ 自 $(t z \breve{u})$ 立 (li) 篇 (wei) 王(wang) 國 (kuo) 號 (hao) 責 (kuei) 霜 (shuang) 王 (wang), “he [Kadphises I] established himself as a king (wang) and used the dynastic title "king of the Kūšann'." This phrase occurs in the Houhan-shu (Annals of the later Han dynasty), and from the same chronicle we lear'n that Kadphises I (K'iu-tsiu$\mathrm{k}$ (io) at the beginning of his reign had to content himself with the more modest title of 貴 (kuei) 霜 (shuang) 拿 (hsi) 侯 (hou). It was only after having defeated certain rivals that he styled himself Kuei-shuang-wang ( $K \bar{u} \bar{s} \bar{a} n s \bar{s} \bar{a} h$ ).

Everybody seems to admit that Kuei-shuang-hsi-hou (Cantonese pronunciation according to Williams' Cantonese dictionary : Kwai-séung-yap-hau) is the Chinese form of

I I give the original phrase as I find it in the Chinese block-print (As. Dep., No. 624, ch. 118, p. 11b) of the Hou-han-shu, belonging to the Asiatic Museum of St. Petersburg. A copy of the same edition has, apparently, been used by Dr. O. Franke, who quotes the same page in his book Zur Kenntniss der Türkvölker und Slythen Zentralasiens (Berlin, 1904 , p. 66). The translation is mainly based on the authority of Dr. Franke, whose rendering of the phrase is, "Er setzte sich selbst als König (wang) ein und führte den dynastischen Titel König von Kuei-shuang."

It can hardly be doubted that the first word of the title $K \bar{u} \bar{s} \bar{a} u \bar{s} \bar{a} \bar{a} h$ represents the name of a race. Cf. the title Gusanavaśasamvardhaka (according to M. Senart's reading of the Manikyāla inscription, Journal Asiatique, Janvier-Février, 1896, p. 8), which Professor Lüders translates by "scion of the Guṣana race" (JRAS., 1909, p. 666). M. Senart (op. cit., p. 12) hesitated between two alternative translations: "auteur de l'accroissement de la race des Koushans" and "issu de la race des Koushans". Dr. Thomas (JRAS. 1906, p. 203) translates the title by "propagator of the Kushan stock".

Dr. Vogel has been so kind as to supply me with his "provisional" reading of one of the inscriptions discovered near Muttra in March, 1912. 'The name of the king seems to be doubtful, but the titles Mahārajja rājātirāja devaputro Kușānaputr[o] are quite clear. It seems most natural to interpret as the name of a race the first part of the title Kuşānaputr[o]. (The long vowel $(\bar{a})$ is also of great interest.)

Considering these facts, I have no doubt that "König der [not von] Kuei-shuang" is the correct German rendering of the title Kueishuang-wang. 
the title Kușanayavuga, which is found on the Kharosthi side of some (type 1) of the coins of Kujula-Kadphises (Kadphises I).

The title Kuei-shuang-hsi-hou being undoubtedly represented on the coins of Kadphises I, it would seem extremely strange if no numismatic equivalent could be found for Kuei-shuang-wang ( $K \bar{u} \bar{s} \bar{a} n$ ša $\bar{\alpha} h$ ) on any pieces of that monarch. Does it not seem natural under these circumstances to consider the syllables Khusanasa, ${ }^{1}$ which we find on the Kharoșthi side of what Mr. Vincent Smith calls type 3 of Kadphises I's coins, as the equivalent of the title $K \bar{u} \bar{s} \bar{a} n n s \bar{\alpha} h$ ? And could not the corresponding syllables XOPANCY of the legend in Greek characters be regarded as a barbaric genitive of *XOPANCA, representing $K \bar{u} \bar{s} \bar{a} n \bar{s} \bar{a} h$ ?

The fact that Khusanasa does not show the genitive termination (Khuşanasa)sa ${ }^{2}$ can easily be accounted for by assuming that the existing $s a(=s \bar{a} h)$ forms a compound with the next word of the Kharoșthi legend.

The following are the full Kharoșthi legends of the types Kadphises I, 1 and 3, according to Mr. Smith's catalogue (I replace the $s k$ of the catalogue by $s$ ):

1 It is just possible that the Kharoșthi letters read Gushanasa by Sir A. Cunningham represent another form of the title Kü $\bar{a} \bar{n} \quad s \bar{a} h$. Unfortunately, however, the letters immediately following Gushanasa in the Panjtar inscription are broken off or mutilated, except the first one, which according to the editor is $R$, or perhaps $N$. "The second letter, which is very doubtful, may be either re, or $h a$, or ne" (Cunningham, Archæological Reports, vol. v, p. 62). The original of the Panjtar inscription being lost (op. cit., p. 61) it will hardly be possible to use it for the purpose of proving or disproving my contentions.

¿ On some coins of Gondophares, who was a $\beta \alpha \sigma \iota \lambda \epsilon \dot{\nu} s \beta \alpha \sigma \lambda \lambda^{\prime} \omega \nu$, we find the title sasasa (Gardner, pp. 104, 106, 189) in Kharoșthi characters, which probably represent the genitive of $s a[n] s a(=s \bar{a} h \bar{a} n \breve{s} \bar{a} h)$. I have not succeeded in ascertaining the presence of the sign representing $m$ (or $n$ ) at the bottom of the akșara read $s a(s a s a)$ by Gardner, the lower part of it being, apparently, damaged on all the coins belonging to the Imperial Hermitage, as well as on the ones reproduced in the catalogues of Gardner and Smith. Cf. the title saansa(an) mentioned below (p. 87, note).

JRAS. 1914. 
Kujula-kasasa Kuṣana-yavugasadhramathidasa (type 1); Khuṣanasa yavüasa [sic], or yaüasa, Kuyula-kaphsasa sa[cha]dhrama[thita]sa (type 3).

Only the transcription of the first legend is followed by a translation ( [coin] of Kujulakasa, the Kușann chief, the pious), and those who contend that Khuspanasa is a genitive singular will hardly be able to interpret the second legend (type 3) without getting into difficulties. Besides having to admit that the equivalent of $K \bar{u} \bar{s} \bar{a} n ~ s \bar{a} h$ (Kuei-shuangwang) cannot be found on the coins of Kadphises I, they will be forced to concede that he called himself "a Küšãn [and] a yavu[g]a" on some of his coins (Khusanasa yavïasa, type 3) and "the yavuga of the Küšñn" (Kusanayavugasa, type 1$)^{1}$ on others. Both difficulties vanish as soon as my interpretation of Khuşanasayavüasa, "king [and] yavu[g]a of the Küšann," is accepted."

We know that the Persian word $\bar{s} a \bar{a} h$ has been rendered by the Greek letters $\sigma a$ (for instance in the name

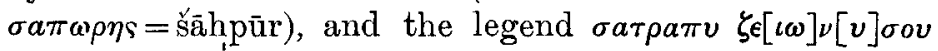

1 The translation of $K$ uei-shuang-wang as " king of the Kūšăn " being certain, Kuei-shuang-hsi-hou and its equivalent Kușanayavuga must mean " yavuga of the Kūšān ".

The Kharosthī legends of Kadphises I's type 1 (Kusanayavugasa) are not only found on pieces bearing that monarch's Greek name on the obverse, but also on coins which he minted conjointly with Hermæus (cf. Catalogue of the Coins in the Indian Museum, Calcutta, vol, i, by Vincent A. Smith, Oxford, 1906, p. 33). The Kharoșțī legend, type 3 (Khuşanasayavilasa), however, is found only on coins belonging exclusively to Kadphises I. This proves Kusanayavugasa (the admitted equivalent of Kuei-shuang-hsi-hou) to be older than Khusanasayavu[g]asa (which, as suggested above, contains the equivalent of Kuei-shuangwang [Kü $\left.\left.\bar{u} \bar{a} n s_{\bar{a} h}\right]\right)$.

It need hardly be pointed out how well the data of the Chinese Chronicle agree with the Kharoșți legends if interpreted according to my view. I do not discuss the types 2 and 4 of Kadphises I, the readings being too uncertain. I have, however, examined them without finding anything disproving my contentions.

2 Accumulations of various titles are very frequent on the numismatic and epigraphic documents of the period, and it will hardly strike anyone as improbable that Kadphises I, after having assumed the more exalted dignity ( $K \bar{u} \xi \bar{a} n \bar{s} \bar{a} h$ ), should retain his old title $($ yavu[g]a) by the side of the new one. 
(Gardner, p. 110) shows that it is not impossible to regard XOPANCY as a genitive. ${ }^{1}$ When composing his catalogue of the coins of the Greek and Scythic kings of Bactria and India, Professor Gardner evidently considered XOPANCY as consisting of two words, (1) XOPAN and (2) CY (cf. Cat., p. 187). Both words the distinguished numismatist places under the heading "Scythic [titles] in Greek letters". He also states that the same word $\sigma v$ occurs on some coins of the king Hermæus. The fact that three of the four words composing the Greek legend

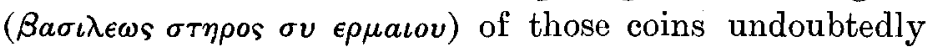
show genitive terminations tends to support my explanation of XOPANCY ${ }^{2}$ as a genitive of ${ }^{*} X O P A N C A$ ( $\left.K \bar{u} s^{r} a n s \bar{s} \bar{a} h\right)$.

Some of Kaniṣka's coins, according to Mr. Smith, bear the following legend (on the obverse): PAONANOPAOKANHPKIKOPANO, Saonano - sao Kanessiki Koṣano, "Kaniṣka the Kușān, king of kings." (I replace Mr. Smith's sh by s.) It is difficult to think of any reason why we should not consider KANHPKI as the first (or the last) word of the legend, and KOPANO PAONANO $P A O$ as his title. This is the only arrangement which enables us to recognize the title $K \bar{u} \bar{s} \bar{a} n$ ša $h$ (in an amplified form, cf. the title $K \bar{u} \bar{u} \bar{a} \bar{a} n$ ša $h \bar{a} n=s \bar{a} h$ mentioned on p. 79) on the coins of the monarch who, surely, was the most prominent Küusāan ruler known to history.

I have already pointed out (Bulletin de l'Académie Impériale des Sciences de St.-Pétersbourg, 1908, p. 1369) that the last three letters (ANO $=\bar{a} n u$ ) of the genitive

1 Professor Rapson (JRAS., 1897, p. 321) and Dr. Thomas (JRAS., 1913, p. 632) also regard XOPANCY as a genitive singular.

2 It is a significant fact that we find the word rajarajasa on the Kharosthi side of several Hermæus (alone without Kadphises I) coins showing $\sigma v$ on the obverse, and that the word rajarajasa never appears on the pieces (mentioned by Gardner, Smith, and von Sallet, Nachfolger

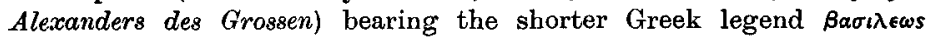

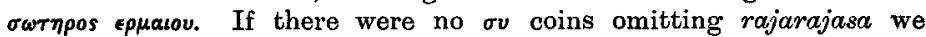
should possess an absolute proof for the fact that $\sigma v$ was a royal title. 
plural PAONANO (according to Mr. Smith "of kings") represent the same termination which appears in the word gyastānu (genitive plural of a theme gyasta, meaning "deus"), and which generally indicates the genitive plural in the second "unknown" language of Eastern Turkestan."

The second ANO of the title KOPANO PAONANO ${ }^{2}$ $P A O$ almost certainly representing $\vec{a} n u$ (Professor Lüders, loc. cit., speaking about the title sāhlanuşāhi, says: "das griechische ANO kann für ānu stehen, wie BO $\triangle O$ für Buddha zeigt"), the rendering of KOPANO by Kuṣānu is, to say the least, possible. That this rendering is more than a possibility is suggested by various circumstances.

The alssara corresponding to the letters ( $g u s a) n a$ in the third line of the Manikyāla inscription (as read by M. Senart, Journal Asiatique, Janv.-Févr. 1896, p. 8, pl. i) shows a distinct hook at the bottom of the mātrka The hook is absent from the mātrka in all other cases (fourteen) where na has been read, but it is clearly visible at the bottom of the aksara representing thu (in thuvam,

1 The $a$-themes of that language generally show the termination $i$ in the nominative singular, and in the article mentioned I compared the

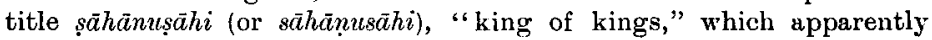
belonged to Kūšăn princes (cf. Sir M. A. Stein's article in the Ind. Ant., 1888, p. 95 sq., and Dr. Fleet's Gupta Inscriptions, p. 8), with the expression gyastânu gyasti (in the language ii "deorum deus"). I arrived at the conclusion that traces of the language ii could be found in the titles of the Kūšān princes. This view has since been accepted by Professors Konow (Festschrift für Vilhelm Thomsen, Leipzig, 1912, p. 96) and Lüders (Sitzungsberichte Kgl. Preuss. Ak. Wiss., 1913, p. 426).

2 Professor Konow accounts for the first $N$ in PAONANO, which he explains as a genitive plural of a theme savan. (derived from $k s a a y+v a n)$, by assuming that the $N$ lost in the nominative singular $P A O$ reappears before the termination of the genitive plural $A N O$. Dr. Salemann draws my attention to the fact that this explanation is

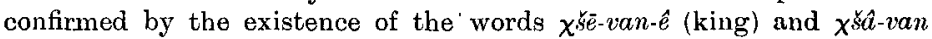
(might) occurring in the "Soghdische Texte" published by Professor F. W. K. Müller (see the index of that edition in the Abhandlungen Kgl. Preuss. Ak. Wiss., 1912 [published 1913], p. 108). Professor Konow tells me that his full explanation of the $N$ will soon appear in the Journal of the German Oriental Society. 
1. 6). M. Senart (op. cit., p. 11) has not overlooked the hook in the third line, and explains it as a "maladresse du lapicide".

On two coins of the Imperial Hermitage of St. Petersburg, and on at least as many specimens of Kadphises' I pieces belonging to the $\mathrm{Kgl}$. Muinzkabinett of Berlin, instead of Kuṣanayavugasa (type 1, cf. above, p. 82) we clearly read Kusanuyavugasa.

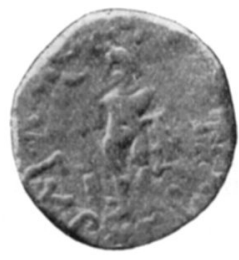

1

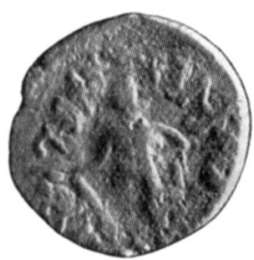

2

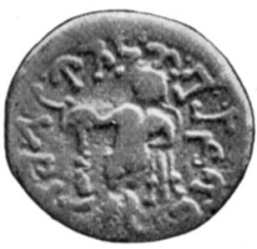

3

Reverses of Kadphises I's coins belonging to the Kgl. Münzkabinett (Nos. 1 and 2), and to the Imp. Hermitage (No. 3). The Greek legend

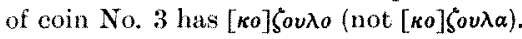

These facts obviously cannot be accounted for by assuming a series of identical blunders, and we shall have to admit that the word $K u s \bar{a} n u(G u s \bar{a} n u)^{1}$ really existed, or to suppose that the die-sinkers of Kadphises I conspired with the stone-cutters of the general Lala in order to puzzle future archæologists.

As soon as the explanation of KOPANO as representing $K u s \bar{a} n u$ is accepted, the interpretation of it as a genitive plural of the theme Kusa suggests itself (cf. gyastānu gyasti, "deorum deus"), and we are fortunately able to show that such a theme did exist at the time of Aśvaghosa's patron.

1 The long $a$ generally being neglected in the Kharosthi writing of

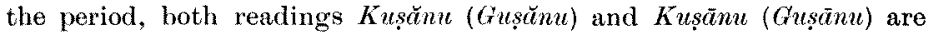
possible. The fact that in the title Kușanaputr[o] (cf. sup., p. 80), on the (Pahlavi) legends deciphered by Drouin and Marquart (cf. sup., p. 79), in Khordadbeh's work, and in other Arabic texts the $\bar{x}$ is clearly marked, suggests the reading Kuşänu (Gusänu) [not Kusănu (Gus̆ănu)]. Cf. also the legend Kidara Kushâna shâhi mentioned by Cunningham, Numismatic Chronicle, 1893, p. 184. 
In Aśvaghoṣa's Sūtrālaṇkāra, which only exists in a Chinese translation, we find the phrase, 㧦 (kü) 沙 $(s h a)$ 種 (chung) 中 (chung) 有 (yiu) 王 (wang) 名 (ming) 悬 (chen) 檀 $(\tan )$ 迦 (kia) 淢 (ni) 杔 (ch'a), "in the Kușa $^{I}$ (kü-sha) race there was a king (wang) called devaputra Kanișka (Kanikșa)." According to Dr. Thomas' translation of the Mahäräjakani[s] lkalekha, which has come down to us in a Tibetan version (Ind. Ant., 1903, p. 356), Aśvaghoșa writes to Kanișka: "Train yourself in the way of your own people: born in the Kusa race (ku-sahi-rigs-su) do you impair not the household law of your ancestors."

Considering the fact that the existence of the theme Kuṣa, meaning " a member of Kanișka's race ", is suggested by circumstances independent of the two texts just quoted, we must refuse to believe that Kuśa in both cases is nothing but an abbreviation of, or a mistake for, $K u s \underline{a} a n a$.

Consequently we are justified in translating the title KOPANO PAONANO PAO by "the emperor of the Kusas", and $K \bar{u} \bar{s} \bar{a} n$ ša $h^{2} b y$ "the king of the Kuṣas (or Küšas) ".

1 It cannot be disputed that liü-sha represents $K u s a$. Cf. M. Sylvain Lévi's translation of the passage, Journal Asiatique, Nov.-Déc., 1896, p. 457. The character 沙 $(s h a)$ is in many transcribed texts the regular representative of $ष(s a)$. See my edition of the Kien-ch'ui-fan-tsan (Aśvaghoșa's Gandistotragāthā in a Chinese transcription, Bibliotheca Buddhica, xv, p. 179). According to Giles' Dict. (No. 2886) 種 (chung), i.a., means "race". I quote the Chinese phrase from the copy of the Tripitaka (vol. xix, fasc. 4, ch. 6, p. 93b) belonging to the Asiatic Museum of St. Petersburg. It was Professor Konow who first pointed out to me that some confirmation could be found for my view (Kusa, not Kuṣana) in Aśvaghoșa's Sütrālañkāra.

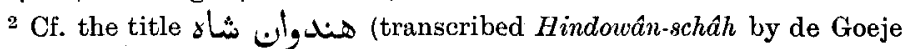
and followed by "dans l'Inde" in the translation of Khordadbeh's

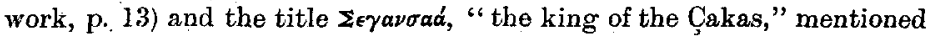

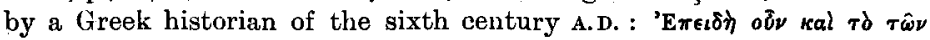

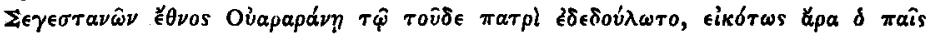

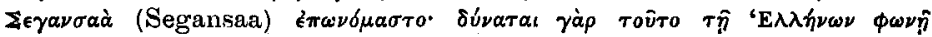

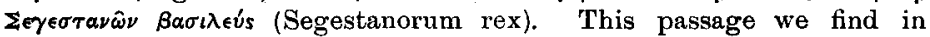
Agathias (ed. Niebuhrius, Bonnæ, MDccexviii, p. 26l). The Latin 
The fact that on some coins of Kadphises I we find the title Kușānu yavuga with the Scythian case suffix (genitive plural) preserved in the half-Präkrtized legend, shows that the first part of Kuṣana yavuga (the form which the title takes on other pieces of the same monarch) must be regarded as a Prākrit genitive plural (Kuṣāna or Kușāna.$^{1}$

Those who accept the interpretation of $K u s ̦ \bar{a} n \alpha$ yavugasa (Kadphises I, type 1) as meaning "of the yavuga of the Kuṣas", will admit that the explanation (the improbability of which has been demonstrated by other considerations, ef. sup., p. 82) of Khuṣanasayavu[g]asa (Kadphises I, type 3) as consisting of two genitives singular becomes impossible.

They will have to concede that Khusana (read $K h u s \bar{a} n a) s a$ is one of the forms of the title $K \bar{u} s \bar{a} n$ $\bar{s} \bar{a} h$, and that the corresponding XOPANCY is a barbaric genitive of *XOPANCA also representing $K \bar{u} s \bar{\alpha} n$ sa $a h$, "king of the Kuṣas (or Kūšas)."

It is a well-known fact that there is a Sanskrit word signifying "store" which the classical writers spell both ways : kośa and $\operatorname{kos} a$. It is much less astonishing that a foreign word should be spelt $K u s$ śa (in the Kani[s]kalekha), and Kusa (in the Sütrālamelkāra). Under these circumstances I do not think it necessary to blame Tibetan scribes for the spelling Kusa, and

equivalents mentioned are those of Bonaventura Vulcanius' translation which accompanies Agathias' Greek text. According to Ammianus Marcellinus (ed. Gardthausen, Lipsiæ, Moccclxxiii, vol. i, p. 173) the title saansaan, "rex regibus imperans," belonged to the Persian king Sapor [II?], and I have no doubt that saansaan is nothing but a clerical error for saansa or saansaa $(=\bar{z} \bar{a} h \bar{a} n \bar{s} \bar{a} h)$.

1 No mechanical reproduction of the newly (March, 1912) discovered Muttra inscription mentioned above (p. 80) being at hand, Dr. Vogel was unable to tell me whether the reading Kușañuputr[o] (instead of Kusainaputr[o]) was possible or not. In any case the interpretation of that title would be identical with the translation of Gusanuva[m]śasamvardhaka (cf. sup., pp. 80, 84), viz. "scion of the Kuṣa (Guṣa) race". 
I believe that both ways of spelling the name were current in India. I think that these considerations enable us to recognize the name of Kaniska's race in the one of the dvipa (Kusadvipa) mentioned immediately after the Śākadvipa by the Matsyapurāna (Sachau, Alberuni's India, vol. i, p. 235). In the Mahāvyutpatti (Bibl. Buddhica, xiii, p. 52) we find among the names of the Cakravartins the Great Kuśa (Mahākuśa), Kuśa, and Upakuśa. The rôle assigned to Kuśa, the son of Rāma, in Indian mythology is certainly not marked enough to explain the inclusion of his name in the chapter just quoted, and it does not seem impossible to connect the Mahākuśa, etc., of the Mahāvyutpatti with the second Aśoka.

Whatever we might think of the derivation of Kusadvipa, Mahäkuśa, etc., we must admit that Aśvaghoṣa is the best imaginable authority on the main question involved, and that Kuṣa (not Kuṣana) was the correct name of the warlike race that gave Kaniṣka to the Buddhist world. 